\title{
EFFICIENCY OF SORPTION MATERIALS ON THE REMOVAL OF LEAD FROM WATER
}

\author{
BIELA, R. ${ }^{*}$ - ŠOPÍKOVÁ, L. \\ Brno University of Technology, Faculty of Civil Engineering, Institute of Municipal Water \\ Management, Žizkova 17, 60200 Brno, Czech Republic \\ (phone: +420-541-147-732; fax: +420-541-147-728) \\ *Corresponding author \\ e-mail: biela.r@fce.vutbr.cz \\ (Received 30 Jun 2016; accepted $22^{\text {nd }}$ Apr 2017)
}

\begin{abstract}
Lead is a highly toxic metal. Given that in the Czech Republic the limit of the concentration of lead in drinking water has recently been changed from $25 \mu \mathrm{g} .1^{-1}$ to $10 \mu \mathrm{g} \cdot 1^{-1}$, the article deals with the removal of lead from water through three sorption materials (Bayoxide E33, GEH and CFH 0818). From the analysis, it is clear that all the sorption materials achieve excellent results in removing lead due to its concentration in the raw water. Overall, the best results in the removal of lead from water were achieved by the sorption material Bayoxide E33. At the same time, the efficiency of sorption materials on the removal of iron and manganese from the water was monitored.
\end{abstract}

Keywords: analysis, column, filtration, measurement, metals, sorbent

\section{Introduction}

Lead $(\mathrm{Pb})$ ranks among the most toxic metals. The most common lead ore is galena $(\mathrm{PbS})$, less common ores are anglesite $\left(\mathrm{PbSO}_{4}\right)$, cerussite $\left(\mathrm{PbCO}_{3}\right)$ and hydrocerussite $\left[\mathrm{Pb}_{3}\left(\mathrm{CO}_{3}\right)_{2}(\mathrm{OH})_{2}\right]$. In the past an anthropogenic source of lead were the exhaust gases of motor vehicles, causing the lead to accumulate on vegetation in the vicinity of roads, polluting the atmospheric water and hence the surface water and groundwater as well. Another source of lead can be the corrosion of the lead parts of water pipes, which, however, is nowadays mostly replaced by pipes of different material. Another source of lead can also be waste water from the processing of ores from ferrous metallurgy, from the production of batteries, or in the glass industry (Pitter, 2009).

In groundwater, the concentrations of lead are in units up to tenths of $\mu \mathrm{g} .1^{-1}$. Higher concentrations of lead in groundwater are only in the areas of lead ore deposits (tenths of mg. $\mathrm{l}^{-1}$ or more) (Hlavínek and Ŕíha, 2004). In sea water the concentration is usually $0.03 \mu \mathrm{g} .1^{-1}$ to $3 \mu \mathrm{g} .1^{-1}$. Waste water from the manufacture and repair of batteries may contain lead in the hundreds of mg. $\mathrm{l}^{-1}$. In the Czech Republic, an average $3 \mu \mathrm{g} . \mathrm{l}^{-1}$ concentration of lead was ascertained in drinking water in the public water mains, although maximum concentrations amounted up to tens of $\mu$ g. $l^{-1}$ (Pitter, 2009).

Currently in the Czech Republic, the highest limit of lead in drinking water is 10 $\mu \mathrm{g} .1^{-1}$ (Decree 252/2004 Coll). This led to a tightening of the limit, as until 24 December 2013 a maximum limit in drinking water of $25 \mu \mathrm{g} .1^{-1}$ applied in accordance with Decree. The guideline value of WHO for lead in drinking water is $0.01 \mathrm{mg} . \mathrm{l}^{-1}$ (WHO, 2011).

Lead has a high accumulation rate in the human body and accumulates mainly in the bones and causes neurotoxicity (WHO, 2011). Inorganic lead compounds are classified as probably carcinogenic to humans (group 2A) by IARC (Ferrante et al., 2014).

Children are more susceptible to lead than adult to higher gastrointestinal uptake and permeable blood-brain barrier (Jarup, 2003). Obvious symptoms of acute lead 
poisoning, such as restlessness, irritability, poor attention, headaches, shivering, abdominal cramps, kidney damage, hallucinations, memory loss and encephalopathy occur at blood lead levels of 100 to $120 \mu \mathrm{g} \cdot \mathrm{dl}^{-1}$ in adults and 80 to $100 \mu \mathrm{g} . \mathrm{dl}^{-1}$ in children (WHO, 2011).

The effects of long-term low-level exposure are mainly neural, affecting the brain, causing behavioural changes and deficits in intelligence levels. The problem has been brought to light by a number of studies in Britain and the USA, although it is the specific studies carried out at Glasgow and Edinburgh Universities which have shown fairly conclusively that exposure to low levels of lead primarily from drinking water has adverse effects on the learning ability of children (Gray, 2008).

It is obvious we will have to deal with the issue of lead removal from drinking water. The next chapter inquires into the number of methods for the removal of metals in water treatment.

\section{Review of Literature}

Toxic heavy metals occur in the natural ecosystem and subsequently are accumulated through either direct intake or food chains in human bodies. Therefore, heavy metals should be eliminated from the environment (Balintova et al., 2016). There are several technological methods for the removal of heavy metals and metalloids in water treatment: precipitation, ion exchange, membrane technologies, adsorption, electrochemical processes, and recently also biological methods (Illavský et al., 2015).

Most specialist articles deal with the removal of arsenic from water applying various methods, for example coagulation (Hering et al., 1997), iron impregnated sand (Vaishya and Gupta, 2003), moving bed active filtration (Newcombe et al., 2006), adsorption (Smith, 1998) and so on.

Every method of heavy metals removal from water has some advantages and disadvantages that we can discuss. For example, the coagulation with iron salt and alum is relatively inexpensive but generates heavy metal-rich sludge. The water treatment technology with iron based surfaces is easily controlled and relatively inexpensive but not normally regenerated and used material may be classed as toxic waste. Ion exchange selectively removes low level of metal ions from contaminated aquifer, despite high concentration of natural component. Waters rich in iron and manganese may require pre-treatment to prevent media clogging. The method is moderately expensive and the regeneration produces metal-rich brine. Membrane technologies have high heavy metals removal efficiency but the pretreatment is usually required. The technologies are relatively expensive, especially if operated at high pressures (Bufa-Dörr et al., 2012).

Electrochemical methods have a long history as water treatment technologies for removal of a wide range of pollutants. However, these methods have never become accepted as a "mainstream" of water treatment technology. These treatment technologies are most suitable for decentralized water treatment and supply drinking water for small communities in remote areas (Gyliene, 2012).

Sorption is a simple, effective, and economically reasonable method for removal of heavy metals, especially due to the option of using a broad spectrum of substances with absorbing capacity - sorbents (Pěkný, 2013). Although activated carbon is the most widely used adsorbent for water treatment, it is very expensive and has high operating costs due to the high price of the activated carbon and to the high water flow rate always 
involved, and these costs can be greatly increased when there are no carbon regeneration units locally (Gong et al., 2004).

Some natural materials (zeolites), but also industrial and agricultural wastes can be used as affordable sorbents. The most tested heavy metal sorbents are oxides and hydroxides of iron, iron hydroxide-coated sand, media with $\mathrm{TiO}_{2}$ or $\mathrm{MnO}_{2}$ layer on the surface and others (Pěkný, 2013).

The objective of this work was to verify the sorption properties of some iron-based sorption materials for the removal of lead from the model water and compare their efficiency.

\section{Materials}

Due to stricter limits of lead in drinking water experimental measurements have been focused on the efficiency of lead removal from water during filtration through different sorption materials. Measurements were carried out at the Faculty of Civil Engineering at the University of Technology in Brno at the laboratory of the Institute of Municipal Water Management.

Three filter materials were used for the experiment, namely Bayoxide E33, GEH, and $\mathrm{CFH}$ 0818. At the same time, the efficiency of the removal of iron and manganese during filtration was also investigated.

Bayoxide (Fig. 1) is a dry crystalline granular sorbent on the basis of iron hydroxide. It was developed by the company Severn Trent in collaboration with the company Bayer AG and is manufactured by the firm LANXESS Deutschland $\mathrm{GmbH}$, Leverkusen, Germany. It is available in two variants, namely Bayoxide E33 and Bayoxide E33P. The difference is that Bayoxide E33 is granulated while Bayoxide E33P is produced in tablets. The material was designed for the removal of arsenic and its advantage is the elimination of $\mathrm{As}^{\mathrm{III}}$ and $\mathrm{As}^{\mathrm{V}}$ along with the removal of iron and manganese. The manufacturer indicates the ability of water treatment during the content of arsenic of 11-5 $000 \mu \mathrm{g} .1^{-1}$ and iron content 50-10 $000 \mu \mathrm{g} . \mathrm{l}^{-1}$ (Ilavský and Barloková, 2008; Konečný, 2016).

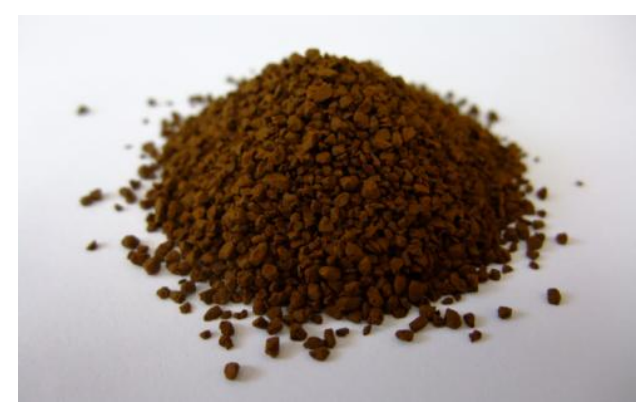

Figure 1. Bayoxide E33

The sorbent material GEH (Fig. 2), created on the basis of granular iron hydroxide, is suitable for the economical and efficient removal of arsenic and antimony from water. The material was created at the University of Berlin in the Department of Water Quality Control. The manufacturer is the German company GEH-Wasserchemie GmbH (Konečný, 2016). It is imported to the Czech Republic by the company Aqua InformConsult s.r.o. Prríbram. The treatment technology involves the adsorption of the 
contaminant into the granular ferric hydroxide (GEH sorbent) that is stored in the reactor, which the treated water flows through. The adsorption capacity of the material is dependent on the operating conditions (Vosáhlo, 2012; Biela and Kučera, 2015).

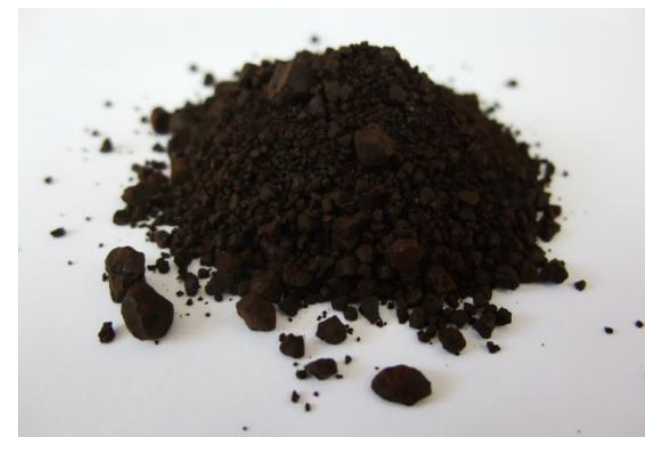

Figure 2. GEH

CFH adsorbent was developed by the company Kemira in Finland. It is a granular medium based on iron hydroxide. Is imported to the Czech Republic by the company Kemwater ProChemie based in Bakov nad Jizerou. On the market there are 2 types of material with the designations CFH 12 and CFH 0818. The difference between these materials is in the grain size. The materials are used to remove $\mathrm{As}, \mathrm{Se}, \mathrm{P}, \mathrm{Ag}, \mathrm{Ni}, \mathrm{Pb}$, $\mathrm{Mo}, \mathrm{Si}, \mathrm{W}, \mathrm{Cu}$ and other metals from water (Šopíková, 2015). For the purpose of the experiment, the finer material CFH 0818 was chosen (Fig. 3).

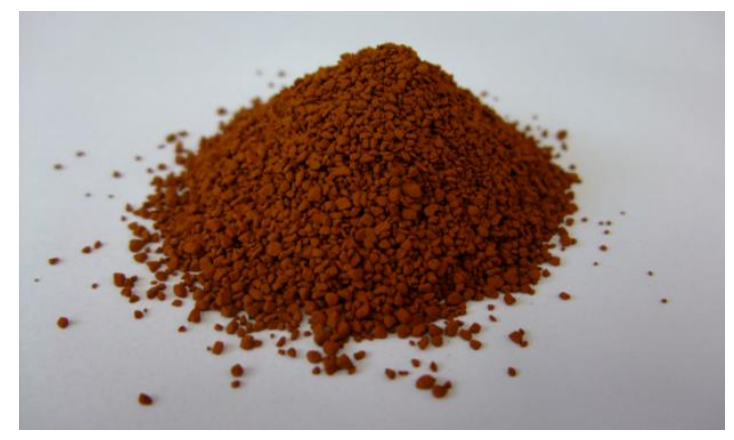

Figure 3. $\mathrm{CFH} 0818$

Table 1. Sorption materials properties overview

\begin{tabular}{cccc}
\hline Parameter/Unit & BAYOXIDE E33 & GEH & CFH 0818 \\
\hline Main ingredient & $\mathrm{FeO}(\mathrm{OH})$ & $\mathrm{Fe}(\mathrm{OH})_{3}+\beta \mathrm{FeOOH}$ & $\mathrm{FeO}(\mathrm{OH})$ \\
Particle size/mm & $0.5-2$ & $0.2-2$ & 1.2 \\
Density/g.cm ${ }^{-3}$ & 0.45 & 1.25 & 1.12 \\
Working pH content & $6.0-8$ & $5.5-6.5$ & $6.5-7.5$ \\
Porosity of the grains/\% & 85 & $72-77$ & $72-80$ \\
Color & amber & dark brown to black & brown to brown-red \\
Description & dry granular & moist granular & dry granular \\
\hline
\end{tabular}




\section{Method of measurement}

Each sorbent material was put into a glass tube with an internal diameter of $4.4 \mathrm{~cm}$, in whose bottom a drainage layer of granules with a diameter of 1-2 cm has been formed, then a layer of glass beads with a diameter of $4 \mathrm{~mm}$ and above it a layer of spheres with a diameter of $2 \mathrm{~mm}$. In this way, the leakage of loose filter material from the column during filtration was prevented. The height of the filter media was $62 \mathrm{~cm}$ on average. The filtration columns were mounted on the wall beside each other.

The entire filtration device consisted of a container with raw water, a pump, a flow meter, a filtration column system and a filtrate container. The diagram of the filtration system for one column is shown in Fig. 4.

Before starting filtration, the incorporation of filter materials was carried out according to the manufacturer's instructions, the column with the sorption materials Bayoxide E33, GEH and CFH 0818 was soaked with tap-water. Subsequently, the filters were rinsed with tap water in the opposite direction than the filtration, i.e. from the bottom to the top, when the water was discharged from washing into the sewerage system. During washing, the column flow rate was chosen so as to avoid the leaching of the filter material, which came into suspension. Washing the filter was usually conducted until no pure water dripped from the colony.

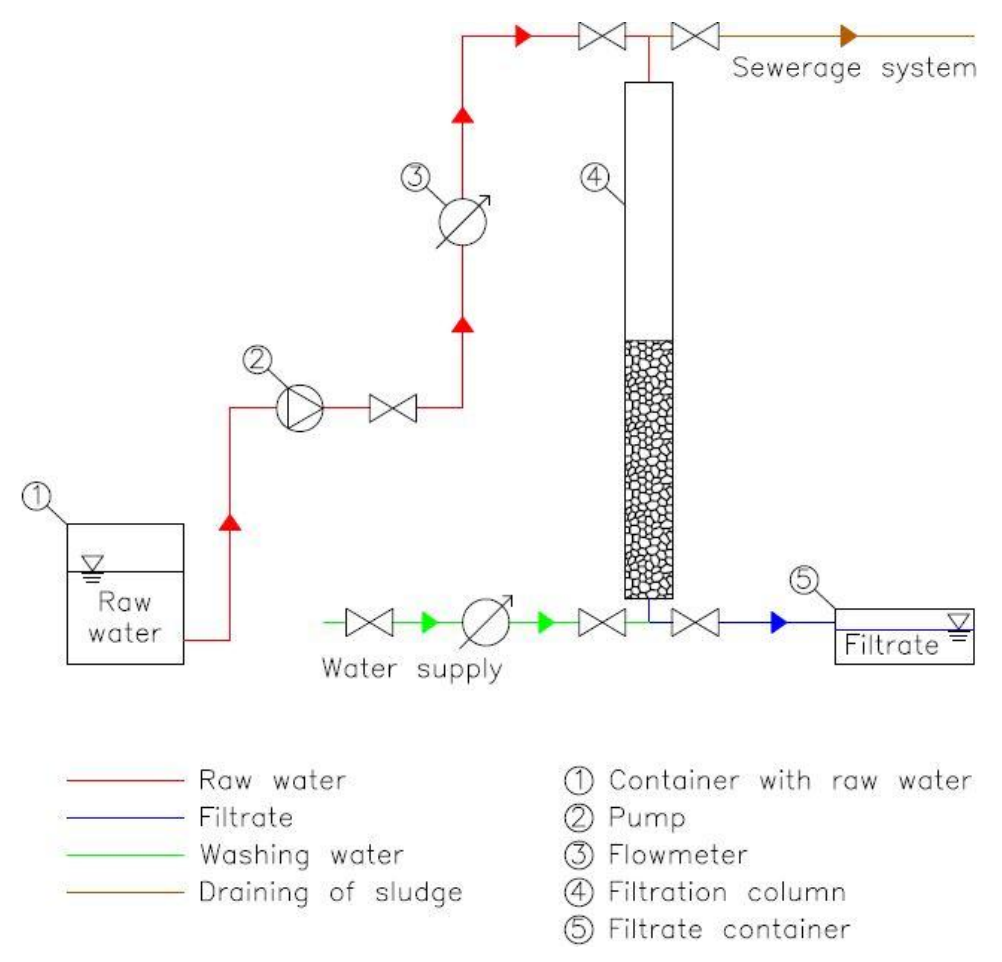

Figure 4. The diagram of the filter device

In the laboratory, raw water from an underground source was simulated by adding chemical concentrates of iron, manganese and lead (Table 2) to drinking water from the Brno municipal water supply. When measuring, the raw water was pumped through a flow meter on which the flow rate was adjusted so as to achieve the empty bed contact time of water in the columns of 2.5 minutes, 7 and 15 minutes. The flow rate depends on the volume of water in the column and the time $(\mathrm{Q}=\mathrm{V} / \mathrm{t})$. Because each material has 
a different porosity - see Table 1, for each sorption material was calculated volume of water in the column and at the required empty bed contact times calculated also the flow rate through the column. In the first column was filtrated water through sorption material Bayoxide E33, after finishing in the second column was filtrated water through sorption material GEH and as last was filtration through sorption material CFH 0818. In each column was always the same sorption material during the whole measurement.

Table 2. Analysis of raw water

\begin{tabular}{ccccc}
\hline $\begin{array}{c}\mathrm{t} \\
{[\mathrm{min}]}\end{array}$ & $\begin{array}{c}\mathrm{pH} \\
{[-]}\end{array}$ & $\begin{array}{c}\mathrm{Fe} \\
{\left[\mathrm{mg} . \mathrm{l}^{-1}\right]}\end{array}$ & $\begin{array}{c}\mathrm{Mn} \\
{\left[\mathrm{mg} . \mathrm{l}^{-1}\right]}\end{array}$ & $\begin{array}{c}\mathrm{Pb} \\
{\left[\mu \mathrm{g} . \mathrm{l}^{-1}\right]}\end{array}$ \\
\hline 0 & 7.48 & 3.070 & 0.233 & 83.6 \\
\hline
\end{tabular}

In the water filtered through the sorption materials, the concentrations for iron, manganese and lead (Table 3) were then set. For determining the concentrations of iron and manganese a spectrophotometer from the laboratory of the Institute of Municipal Water Management was used. Lead concentrations were determined by an accredited laboratory of the National Health Institute in Brno.

Table 3. Analysis after filtration through the sorption materials Bayoxide, GEH and CFH

\begin{tabular}{ccccccccccc}
\hline \multicolumn{4}{c}{ Bayoxide E33 } & \multicolumn{3}{c}{ GEH } & \multicolumn{3}{c}{ CFH 0818 } \\
\hline $\mathrm{t}$ & $\mathrm{Fe}$ & $\mathrm{Mn}$ & $\mathrm{Pb}$ & $\mathrm{Fe}$ & $\mathrm{Mn}$ & $\mathrm{Pb}$ & $\mathrm{Fe}$ & $\mathrm{Mn}$ & $\mathrm{Pb}$ \\
{$[\mathrm{min}]$} & {$\left[\mathrm{mg} . \mathrm{l}^{-1}\right]$} & {$\left[\mathrm{mg} .1^{-1}\right]$} & {$\left[\mu \mathrm{g} .1^{-1}\right]$} & {$\left[\mathrm{mg} .1^{-1}\right]$} & {$\left[\mathrm{mg} . \mathrm{l}^{-1}\right]$} & {$\left[\mu \mathrm{g} . \mathrm{l}^{-1}\right]$} & {$\left[\mathrm{mg} . \mathrm{l}^{-1}\right]$} & {$\left[\mathrm{mg} . \mathrm{l}^{-1}\right]$} & {$\left[\mu \mathrm{g} . \mathrm{l}^{-1}\right]$} \\
\hline 2.5 & 0.113 & 0.033 & 3.42 & 0.161 & 0.097 & 5.05 & 0.212 & 0.028 & 11.30 \\
7 & 0.116 & 0.031 & 2.71 & 0.120 & 0.027 & 3.29 & 0.201 & 0.032 & 6.86 \\
15 & 0.114 & 0.031 & 2.50 & 0.118 & 0.031 & 3.29 & 0.171 & 0.032 & 3.91 \\
\hline
\end{tabular}

Lead removal efficiency for the individual sorption materials in 2.5, 7, and 15 minutes was calculated applying the following formula:

$$
\eta=\frac{C_{R W}-C_{F}}{C_{R W}}
$$

where:

$\eta \ldots . . .$. contamination removal efficiency;

$\mathrm{C}_{\mathrm{RW}} \ldots$. concentration of contamination in raw water $\left[\mathrm{mg} . \mathrm{l}^{-1}\right]$;

$\mathrm{C}_{\mathrm{F}} \ldots \ldots$. concentration of contamination after filtering $\left[\mathrm{mg} . \mathrm{l}^{-1}\right]$.

\section{Results and discussion}

The experimental measurement was performed only once, but from the analysis it is clear that all the sorption materials achieve excellent results in removing lead due to its 
concentration in the raw water. After a 2.5 minute empty bed contact time of water in the column a concentration of lead in water slightly higher than the present current limit of Decree 252/2004 Coll was only measured in the filtrate through the sorption material CFH 0818. After 7 minutes, the lead concentration in all water samples after filtration through the sorption materials was lower than the maximum limit in drinking water. With longer time residences, a more significant reduction in the concentration of lead did not occur (Fig. 5).

The best results in the removal of lead from water were achieved by the material Bayoxide E33, which demonstrated the greatest reduction in the $\mathrm{Pb}$ content during the shortest empty bed contact time. In the case of this material, as well as sorption material $\mathrm{GEH}$, it is more of a contact filter in the removal of lead from water, since the concentration of lead in water does not change much during the empty bed contact time. For the material CFH 0818, the removal of $\mathrm{Pb}$ is dependent on time.

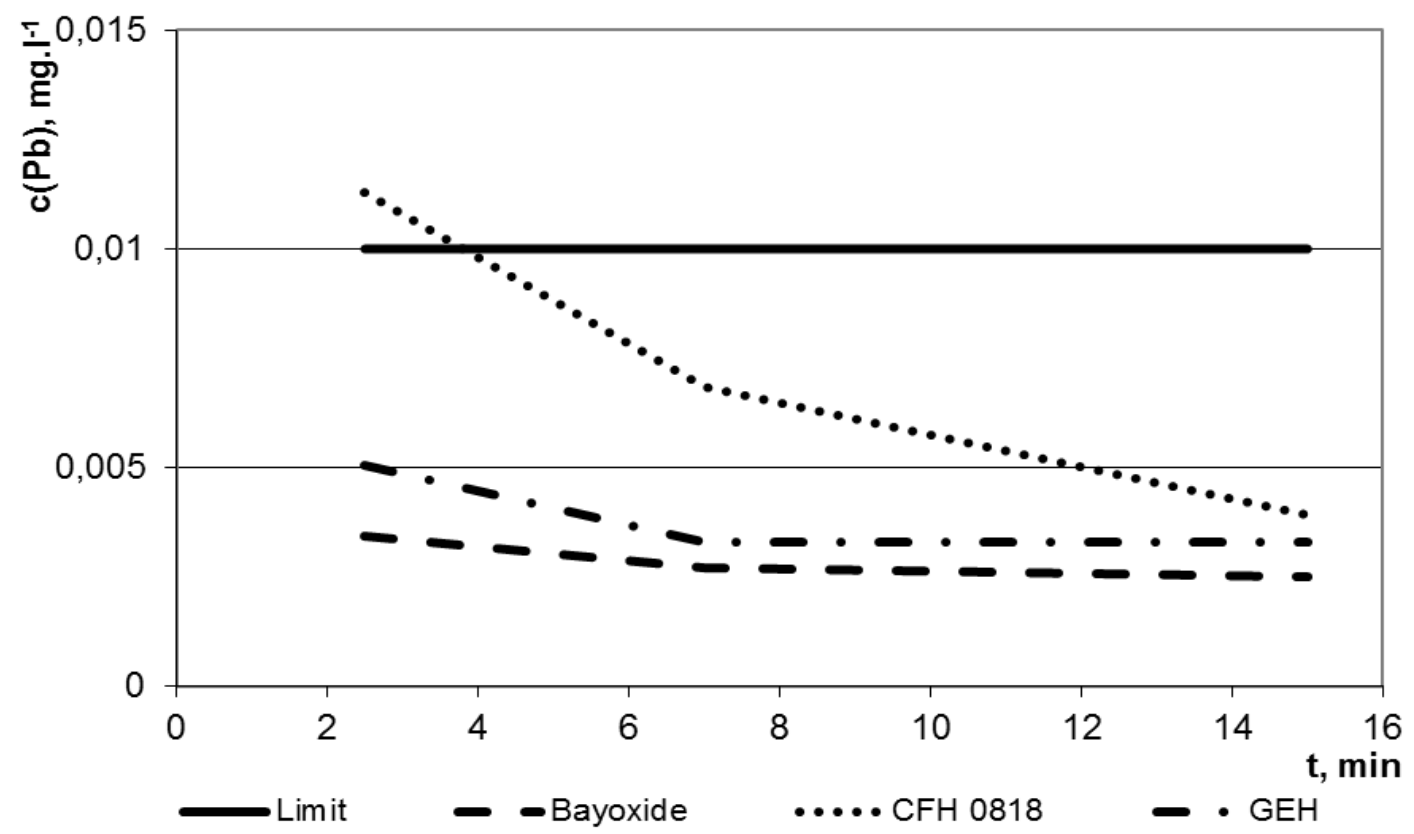

Figure 5. Removal of lead from water by sorption materials

Efficiency of sorption materials on the removal of lead from water shows Table 4 and Figure 6. The table shows that the material Bayoxide E33 achieved after 15 minutes empty bed contact time $97.0 \%$ efficiency of lead removal from water, the sorption material GEH was less effective with efficiency $96.1 \%$ and the sorption material CFH 0818 had the lowest efficiency $95.3 \%$.

Table 4. Efficiency of sorption materials on the removal of lead from water

\begin{tabular}{cccc}
\hline & & $\eta[\%]$ \\
\hline $\mathrm{t}[\mathrm{min}] /$ material & Bayoxide E33 & GEH & CFH 0818 \\
\hline 2.5 & 95.9 & 94.0 & 86.5 \\
7 & 96.8 & 96.1 & 91.8 \\
15 & 97.0 & 96.1 & 95.3 \\
\hline
\end{tabular}




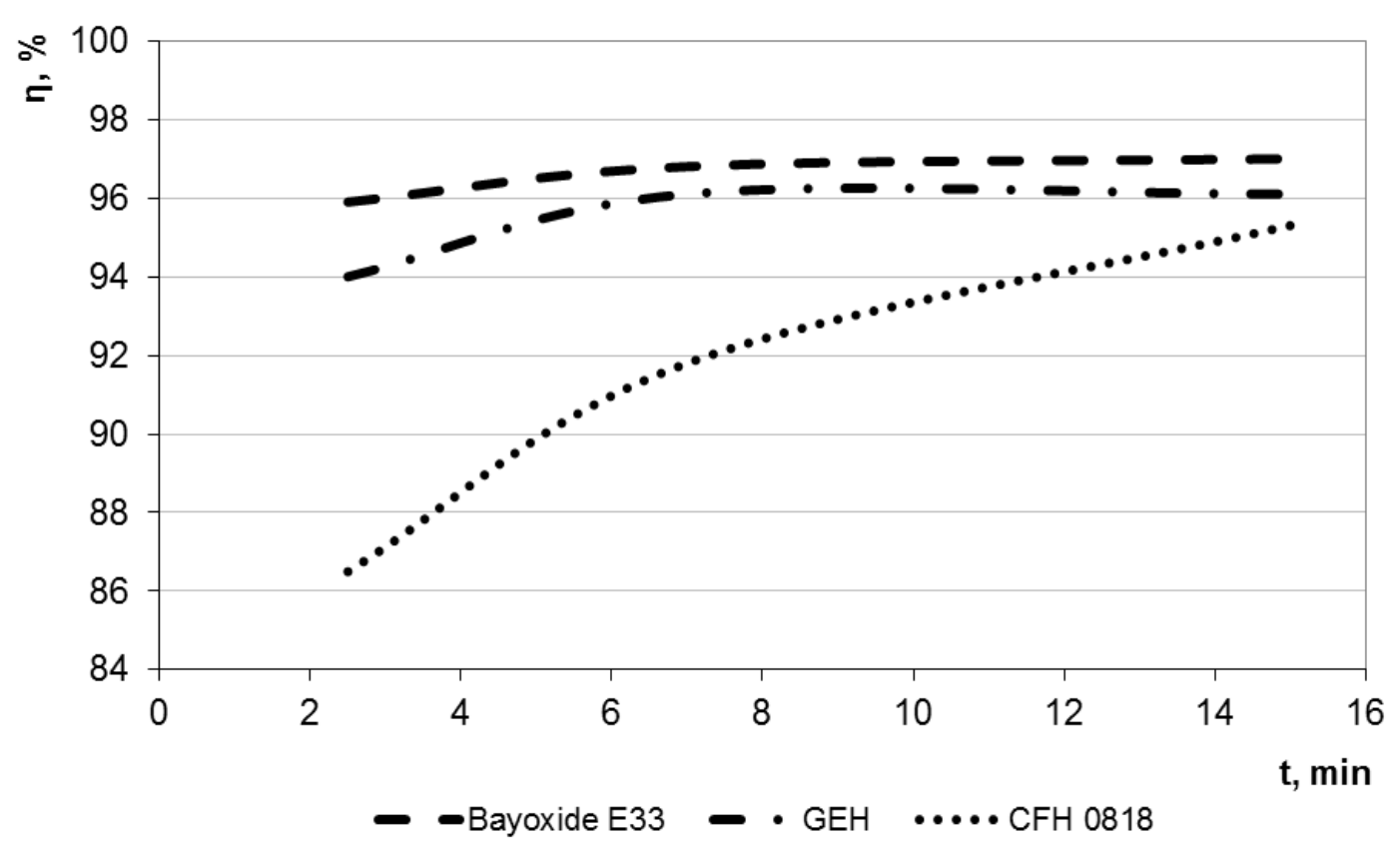

Figure 6. Efficiency of sorption materials on the removal of lead from water

Through measuring it was also determined how the used filter materials remove iron and manganese from water. After a 2.5 minute empty bed contact time, the two materials demonstrated the ability to remove iron under the limit for drinking water of $0.2 \mathrm{mg} . \mathrm{l}^{-1}$, while the concentration of $\mathrm{Fe}$ after filtration through the material CFH 0818 was after this period only slightly above the threshold $\left(0.212 \mathrm{mg} .1^{-1}\right)$. The most effective for removing iron from water was indicated to be the sorption material Bayoxide E33. This obviously concerns contact filtration. The concentration of iron after filtration through the materials GEH and CFH 0818 slowly decreases with time.

When removing manganese from water, the sorbents Bayoxide E33 and CFH 0818 reached almost comparable results, after 2.5 minutes the filtrates show $\mathrm{Mn}$ concentration under the limit for drinking water $\left(0.05 \mathrm{mg} . \mathrm{l}^{-1}\right)$. Apparently this concerns contact filtration. After filtration through the GEH material, the concentration of manganese in the water got under the limit after 7 minutes.

\section{Conclusions}

The results showed that by using sorption materials Bayoxide E33 and GEH it is possible to reduce the lead content from over-limit values after only 2.5 minutes to below the values indicated by the Ministry of Health Czech Republic by Decree 252/2004 Coll., with filtration through the sorption material CFH 0818, the lead concentrations are only slightly above the threshold after this time. Overall, the best results in the removal of lead from water were achieved by the sorption material Bayoxide E33. Efficiency of lead removal from water by this sorption material was 97.0\% after 15 minutes empty bed contact time. The sorption material GEH was less effective with efficiency $96.1 \%$ after 15 minutes empty bed contact time and the sorption material $\mathrm{CFH} 0818$ had the lowest efficiency 95.3\%. Furthermore, it was shown that the sorption materials used have an effect on the removal of iron and 
manganese from water. The concentration of iron in the filtrate managed to be brought under the limit value of $0.2 \mathrm{mg} . \mathrm{l}^{-1}$ in all sorption materials and the concentration of manganese in the filtrate managed to be brought under the limit value of $0.05 \mathrm{mg}^{-1} \mathrm{l}^{-1}$ in all sorption materials.

Acknowledgments. The paper was prepared under the solution of the grant project on special research at Brno University of Technology titled "Efficiency monitoring of water treatment processes in microcontamination elimination" (FAST-S-15-2701).

\section{REFERENCES}

[1] Balintova, M., Demcak, S., Pagacova, B. (2016): A study of sorption heavy metals by natural organic sorbents. - International Journal of Energy and Environment 10: 189-194.

[2] Biela, R., Kučera, T. (2015): Arsenic removal from water by using sorption materials. In: Al Ali, M., Platko, P. (ed.) Advances and Trends in Engineering Sciences and Technologies, Taylor \& Francis Group, Leiden.

[3] Bufa-Dörr, Z., Borsányi, M., Tor, A. (2012): Guide to the selection of water treatment processes for removal of metals. - In: Ersoz, M., Barrott, L. (ed.) Best practice guide on metals removal from drinking water by treatment, IWA Publishing, London.

[4] Decree 252/2004 Coll (2004): The decree establishing the health requirements for drinking and hot water and the frequency and scope of drinking water control. Ministry of Health of the Czech Republic, Prague. (in Czech)

[5] Ferrante, M., Conti, G., Rasic-Milutinovic, Z., Jovanovic, D. (2014): Health effects of metals and related substances in drinking water. - IWA Publishing, London.

[6] Gong, R., Ding, Y., Li, M., Yang, C., Liu, H., Sun, Y. (2004): Utilization of powered peanut hull as biosorbent for removal of anionic dyes from aqueous solution. - Dyes and Pigments 64: 187-192.

[7] Gray, N. F. (2008): Drinking water quality. - Cambridge University Press, New York.

[8] Gyliene, O. (2012): Electrochemical treatment methods. - In: Ersoz, M., Barrott, L. (ed.) Best practice guide on metals removal from drinking water by treatment, IWA Publishing, London.

[9] Hering, J. G., Chen, P., Wilkie, J. A., Elimelech, M. (1997): Arsenic removal from drinking water during coagulation. - Journal of Environmental Engineering 123: 800-807.

[10] Hlavínek, P., Ríha, J. (2004): Water quality in watershed. - Brno University of Technology, Brno. (in Czech)

[11] Ilavský, J., Barloková, D. (2008): New sorption materials in the removal of metals from water. In: Proceedings of Drinking Water 2008, W\&ET Team, České Budějovice. (in Czech)

[12] Ilavský, J., Barloková, D., Munka, K. (2015): Antimony removal from water by adsorption to iron-based sorption materials. - Water Air Soil Pollution 226:1.

[13] Jarup, L. (2003): Hazards of heavy metal contamination. - British Medical Bulletin 68: 67-82.

[14] Konečný, J. (2016): Assessment of the effectiveness of filter material DMI-65 on removing metals from water. Diploma thesis, Institute of Municipal Water Management, Brno University of Technology, Brno. (in Czech)

[15] Newcombe, R. L., Hart, B. K., Möller, G. (2006): Arsenic removal from water by moving bed active filtration. - Journal of Environmental Engineering 132: 5-12.

[16] Pěkný, M. (2013): Removal of selected metals from the water. Diploma thesis, Institute of Municipal Water Management, Brno University of Technology, Brno. (in Czech)

[17] Pitter, P. (2009): Hydrochemistry. - University of Chemistry and Technology Prague, Prague. (in Czech)

[18] Smith, E. H. (1998): Surface complexation modeling of metal removal by recycled iron 
sorbent. - Journal of Environmental Engineering 124: 913-920.

[19] Šopíková, L. (2015): Removal of lead and other metals from water. Diploma thesis, Institute of Municipal Water Management, Brno University of Technology, Brno. (in Czech)

[20] Vaishya, R. Ch., Gupta, S. K. (2003): Arsenic removal from groundwater by iron impregnated sand. - Journal of Environmental Engineering 129: 89-92.

[21] Vosáhlo, J. (2012): Evaluation of water quality in drinking water treatment plant Mokošín. Diploma thesis, Institute of Municipal Water Management, Brno University of Technology, Brno. (in Czech)

[22] World Health Organization (2011): Lead in Drinking Water. Report No. WHO/SDE/WSH/03.04/09/Rev/1, World Health Organization, Geneva. 